\title{
Statistical methods for batch screening of input populations by stage and group in COVID-19 nucleic acid testing
}

\section{Author:}

\section{Cheng Yuan yuan}

Address for correspondence:

\author{
E-mail:henuhh@outlook.com
}

\section{Affiliation \\ Henan University Huaihe hospital, Kaifeng City, Henan Province, China.}

\begin{abstract}
Purpose: To screen for COVID-19 patients in immigration using minimal nucleic acid testing (NAT). Methods: In the first phase, nasopharyngeal swab samples from the inbound population were numbered and grouped. The samples in the group were mixed together, and a NAT test was performed. When the test result is negative, it means that everyone in the group is not infected and the screening of the group is complete. When the test results were positive, the group moved on to the second stage. In the second stage, all samples in the positive group will be tested individually for NAT.

Results: The advantages and considerations of the method are discussed. Prevalence in the incoming population was a determinant of the sample size within the group. The lower the incidence, the larger the sample size within the group, the higher the savings in NAT and testing costs. Conclusion: This method has significant efficiency and cost advantages in COVID-19 screening. It can also be used to screen other populations, such as community populations and people at high risk of infection, etc.
\end{abstract}

Key words: COVID-19; NAT; nucleic acid testing; screening; nasopharyngeal swab

\section{Background}

NOTE: This preprint reports new research that has not been certified by peer review and should not be used to guide clinical practice. 
medRxiv preprint doi: https://doi.org/10.1101/2020.04.02.20050914; this version posted April 28, 2020. The copyright holder for this preprint (which was not certified by peer review) is the author/funder, who has granted medRxiv a license to display the preprint in perpetuity.

It is made available under a CC-BY-NC-ND 4.0 International license .

Since the WHO declared COVID-19 (Corona Virus Disease 2019) a global pandemic on March

$11,2020,{ }^{[1]}$ the number of Chinese arrivals has reached 600,000 by March 15, 2020, ${ }^{[2]}$ and 44 new confirmed cases have been detected from the arriving population. ${ }^{[3-7]}$ Starting from March 19, 2020, cities such as Shenzhen, Guangzhou, Shanghai, and Beijing have implemented the policy of nucleic acid testing (NAT) for all inbound persons. ${ }^{[8-11]}$

\section{Method}

The formula used is as follows:

$$
\begin{gathered}
p=\frac{d}{t}=\frac{1}{q} \ldots \ldots \ldots \\
y=\frac{1}{p * x}+x \ldots \ldots \ldots \ldots \\
y_{\text {min }}=\sqrt{q}+x \approx 2 \sqrt{q}=2 x
\end{gathered}
$$

$\mathrm{R}$ software (Version 3.6.3) code to calculate $\mathrm{y}$ is as follows:

$$
\begin{aligned}
& 1 p<- \\
& 2 x<-c(2:(1 / p)) \\
& 3 y<-1 /\left(p^{*} x\right)+x \\
& 4 t<- \text { data.frame }(x, y) \\
& 5 \text { View }(t)
\end{aligned}
$$$$
\text { \#input value of incidence rate }
$$

where $p$ is the incidence of the incoming population, $d$ is the number of confirmed cases in the incoming population, $t$ is the number of concurrent incoming population, $q$ is the number of incoming persons bringing one COVID-19 patient, $y$ is the number of NATs, $x$ is the number of samples per group, and $y_{\min }$ is the minimum number of NATs. According to equation (1), when $d$ $=44, t=60,000, p=0.7333(1 / 10,000), q=13,637$. The incidence in the inbound population was $0.7333(1 / 10,000)$. On average, for every 13,637 entries, one COVID-19 patient was brought in. In order to identify the patient, a COVID-19 fluorescence RT-PCR test had to be performed on 13,637 entry persons. At $160 R M B$ per test, the cost of 13,637 NATs is 2.18 million $R M B$. In order to achieve the same detection effect with the lowest number of NATs, a staged, batch screening approach is 
medRxiv preprint doi: https://doi.org/10.1101/2020.04.02.20050914; this version posted April 28, 2020. The copyright holder for this preprint (which was not certified by peer review) is the author/funder, who has granted medRxiv a license to display the preprint in perpetuity.

It is made available under a CC-BY-NC-ND 4.0 International license .

recommended (Figure 1).

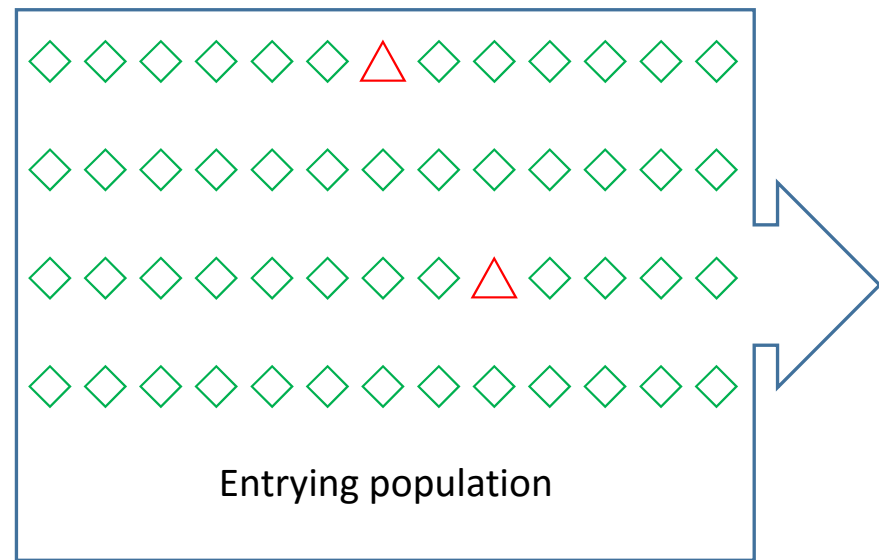

stage one

group 1 (sample A)

group 2 (sample A)

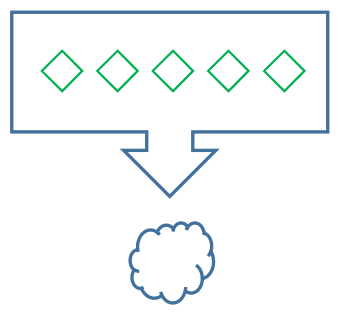

$(-)$

$(+)$

\section{legend \\ $\diamond$ : Uninfected person or sample \\ $\triangle$ : Infected person or sample \\ wixed sample}

group 2 (sample B)

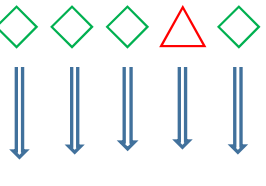

$(-)(-)(-)(+)(-)$

Figure 1 Schematic diagram of the process of phased batch screening in groups.

In the first stage, all arrivals are numbered, grouped, and each $x$ is grouped. In the same group, a double nasopharyngeal swab was taken from each person, called sample A and sample B, and all sample A in the same group was mixed together for a single NAT test. When this test is negative, it means that everyone in the group is not infected and the test for that group is over. When a test result is positive, it means that at least one person in the group has a positive sample, and this group is called the "positive group", and all samples in the positive group go on to the second stage of testing.

In the second stage, NAT was performed on all samples B in the positive group one by one to find out which sample caused the positive result and to screen the corresponding patients.

After two stages of bulk screening in groups, only $y$ NAT is required, $q-y$ NAT is saved. 
medRxiv preprint doi: https://doi.org/10.1101/2020.04.02.20050914; this version posted April 28, 2020. The copyright holder for this preprint (which was not certified by peer review) is the author/funder, who has granted medRxiv a license to display the preprint in perpetuity.

It is made available under a CC-BY-NC-ND 4.0 International license .

We derive the minimum value of $y$ by calculating $\mathrm{x}$. The smaller the $p$, the larger the $q-y$, the more NATs can be saved and the greater the detection cost savings.

For example, assuming $p$ was $0.733 / 100,000$, then $q$ was 13,637 , according to formulas (1), (2), (3) and code of $R$ software 3.63, when $x$ was 117 , the minimum value of $y$ was 234; that was, 13,637 people were divided into 117 groups, each group of 117 people, the minimum value of NAT was 234, instead of 13,637. Each group of 117 people were taken double samples, with 234 nasopharyngeal swabs, as sample A and sample B, respectively. Each group had 117 samples A and 117 samples B, and all samples A mixed together for one NAT. When the test result was negative, it means that the test result of all 117 people was negative, the test of that group was over. When the test result was positive, it means that at least one of the 117 people tested positive. All samples B in the positive group underwent a second stage of testing. In the second stage, all samples B from the positive group were tested individually with NAT for a total of 117 tests. As a result, one patient was screened from 13,637, requiring only 234 NATs, saving 13,403 tests compared to 13,637 NATs. On average, each person entering the country pays only $2.8 R M B$ instead of $160 R M B$ for NAT, which equates to a savings of 2.14 million $R M B$ in testing costs, a 98.3 per cent savings. The savings rate was higher if two or more patients were found in the same group, or if the method was repeated in the positive group. The cost of NAT was at least 960,000 RMB, based on the average of more than 6,000 test visits per day in Beijing. Using this method, Beijing can save 940,000 RMB per day in testing costs and 28.2 million $R M B$ in 30 days. Based on the daily average of 120,000 passengers entering China through land ports, seaports and airports, the cost of testing can be saved by 18.83 million $R M B$ in 30 days, which was $R M B 565$ million.

\section{Conclusion}

The method is not limited to screening of inbound populations, but can also be used to screen community populations and at-risk populations. ${ }^{[12-27]}$

It should be noted that $\mathrm{p}$ is the determinant of the number of people in each group $x$. The lower the $p$, the greater the value of $x$, the greater the value of $q-y$ and vice versa (Table 1, Figure 2, Figure 3). 
medRxiv preprint doi: https://doi.org/10.1101/2020.04.02.20050914; this version posted April 28, 2020. The copyright holder for this preprint (which was not certified by peer review) is the author/funder, who has granted medRxiv a license to display the preprint in perpetuity.

It is made available under a CC-BY-NC-ND 4.0 International license.

Table 1: Relationship between incidence, sample size, and savings rate

\begin{tabular}{|c|c|c|c|c|}
\hline$p(1 / 10,000)$ & $q$ & \multicolumn{2}{c|}{$y_{\min }$} & Percentage saved (\%) \\
\hline 10.00 & 1,000 & 32 & 64 & 93.6 \\
\hline 5.00 & 2,000 & 45 & 90 & 95.5 \\
\hline 3.33 & 3,000 & 55 & 110 & 96.3 \\
\hline 2.50 & 4,000 & 64 & 128 & 96.8 \\
\hline 2.00 & 5,000 & 71 & 142 & 97.2 \\
\hline 1.67 & 6,000 & 78 & 156 & 97.4 \\
\hline 1.43 & 7,000 & 84 & 168 & 97.6 \\
\hline 1.25 & 8,000 & 90 & 180 & 97.8 \\
\hline 1.11 & 9,000 & 95 & 190 & 97.9 \\
\hline 1.00 & 10,000 & 100 & 200 & 98.0 \\
\hline 0.91 & 11,000 & 105 & 210 & 98.1 \\
\hline 0.83 & 12,000 & 110 & 220 & 98.2 \\
\hline 0.77 & 13,000 & 115 & 230 & 98.2 \\
\hline 0.71 & 14,000 & 119 & 238 & 98.3 \\
\hline 0.67 & 15,000 & 123 & 246 & 98.4 \\
\hline
\end{tabular}

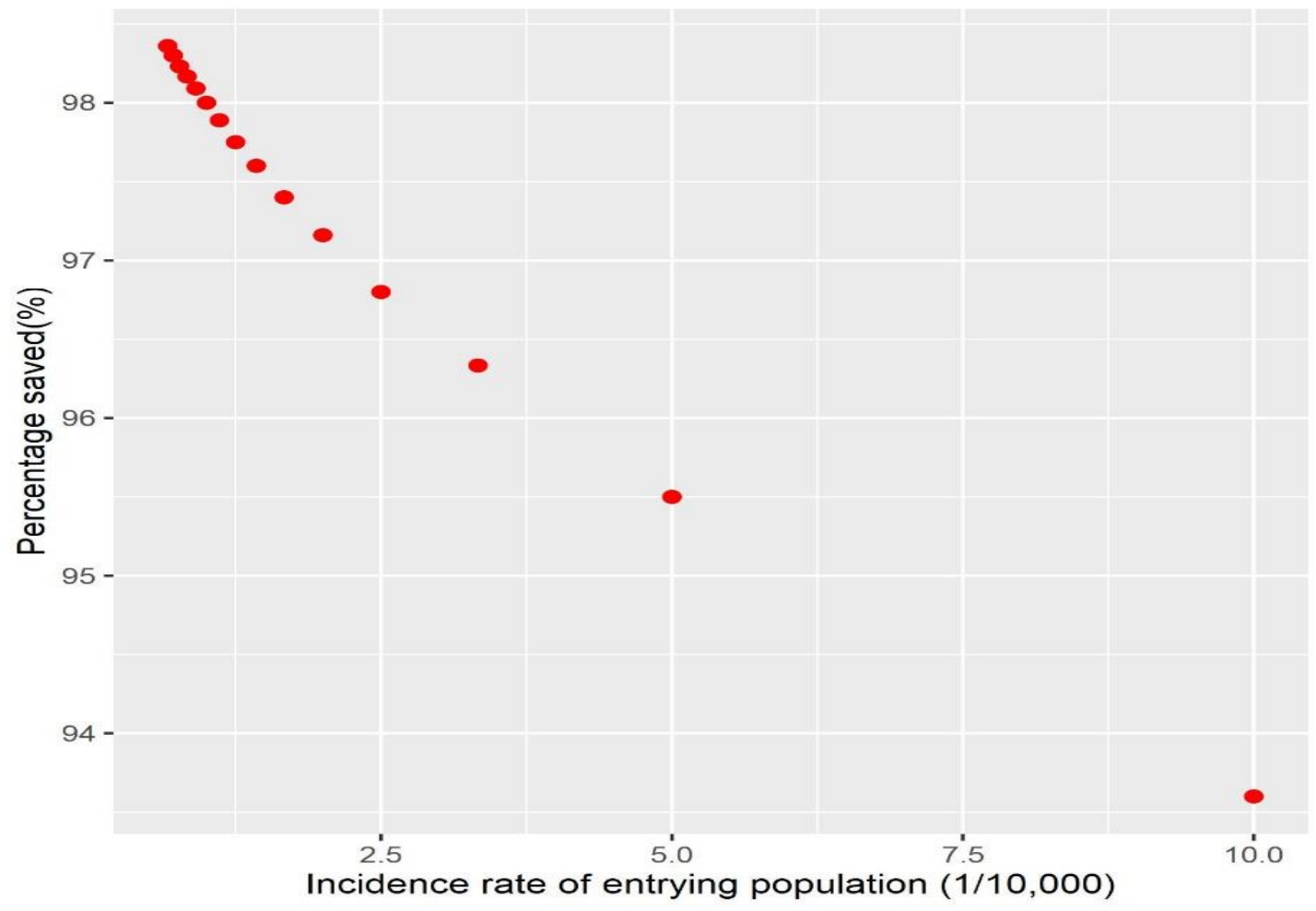

Figure 2 Scatterplot of incidence and percentage saved for the entrying population. The relationship between the incidence rate and the percentage of savings can be seen, with the lower the incidence 
medRxiv preprint doi: https://doi.org/10.1101/2020.04.02.20050914; this version posted April 28, 2020. The copyright holder for this preprint (which was not certified by peer review) is the author/funder, who has granted medRxiv a license to display the preprint in perpetuity.

It is made available under a CC-BY-NC-ND 4.0 International license .

rate, the greater the percentage of savings.

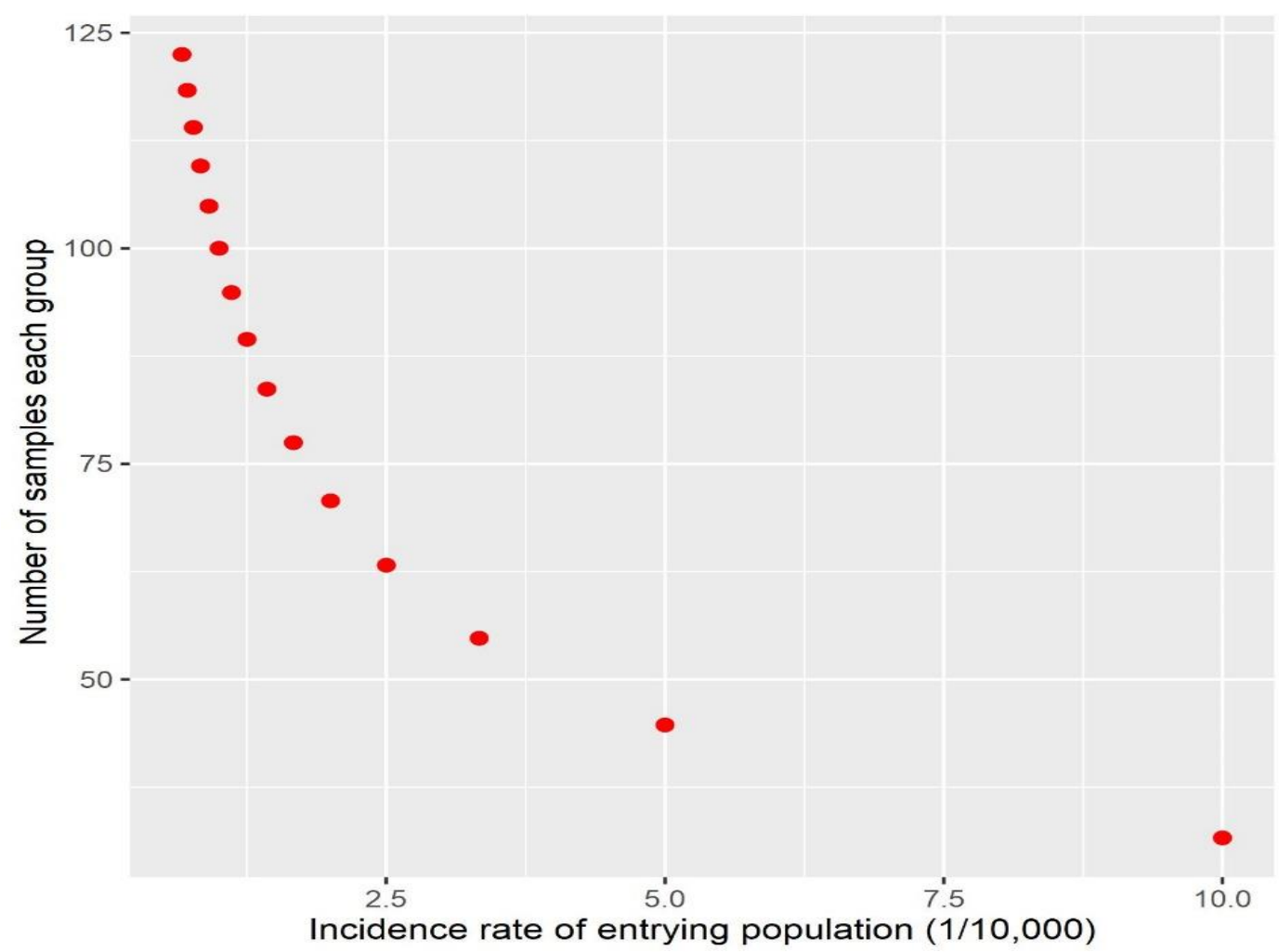

Figure 3 Scatterplot of incidence rates in the incoming population versus sample size per group. It can be seen that the incidence in the inbound population is related to the sample size per group, the lower the incidence, the larger the sample size per group, the more NATs can be saved.

There are many factors that affect $p$, such as international situation, country, city, observation period, customs policy, and the characteristics of the population entering the country. Sometimes these factors cause large fluctuations in $p$ and require timely monitoring of $p$ and adjustment of $x$ according to Equation (2). when $p$ fluctuates within a certain range, $x$ should be adjusted according to the maximum value of $p$.

\section{Reference:}

[1] WHO Director-General's opening remarks at the media briefing on COVID-19 - 11 March 2020. https://www. who. int/dg/speeches/detail/who- 
medRxiv preprint doi: https://doi.org/10.1101/2020.04.02.20050914; this version posted April 28, 2020. The copyright holder for this preprint (which was not certified by peer review) is the author/funder, who has granted medRxiv a license to display the preprint in perpetuity.

It is made available under a CC-BY-NC-ND 4.0 International license.

director-general-s-opening-remarks-at-the-media-briefing-on-covid19---11-march-2020.

[2] http://news. cyol. com/app/2020-03/16/content 18516985. htm. [2020-03$\underline{16]}$

[3] http://www. nhc. gov.cn/xcs/yqtb/202003/37c1536b6655473f8c2120ebdc4757 31. shtm1. [2020-03-12]

[4] http://www. nhc.gov.cn/xcs/yqtb/202003/816e6f71236b4dca96378df5f6f4ae 53. shtm1. [2020-03-13]

[5] http://www. nhc.gov.cn/xcs/yqtb/202003/ec0119a5881543288efd5b5c800838 7b. shtm1. [2020-03-14]

[6] http://www. nhc. gov.cn/xcs/yqtb/202003/8331f126d3854413b6ea323009fbbc c5. shtm1. [2020-03-15]

[7] https://www. sznews. com/news/content/202003/19/content 22979893 0. htm. [2020-03-19]

[8] http://www. nhc. gov.cn/xcs/yqtb/202003/114113d25c1d47aabe68381e836f06 a8. shtm1. [2020-03-16]

[9] http://economy. southen. com/e/202003/25/content 190640969. htm. [ 2020-03-25]

[10] http://www. gov. cn/xinwen/2020-03/24/content 5494829. htm\#1. [2020-0324]

[11] http://www. xinhuanet. com/local/2020-03/24/c 1125762120.htm. [2020-0324]

[12] Ye B, Fan C, Pan Y, Ding R, Hu HX, Xiang ML. Zhonghua Er Bi Yan Hou Tou Jing Wai Ke Za Zhi. 2020;55(0):E003. doi:10.3760/cma. j. cn11533020200223-00116

[13] Ai T, Yang Z, Hou H, et al. Correlation of Chest CT and RT-PCR Testing in Coronavirus Disease 2019 (COVID-19) in China: A Report of 1014 Cases [published online ahead of print, 2020 Feb 26]. Radiology. 2020;200642. doi:10. 1148/radiol. 2020200642

[14] Zhao W, Zhong Z, Xie X, Yu Q, Liu J. Relation Between Chest CT Findings and Clinical Conditions of Coronavirus Disease (COVID-19) Pneumonia: A Multicenter Study [published online ahead of print, 2020 Mar 3]. AJR Am J Roentgenol. 2020;1-6. doi:10.2214/AJR. 20. 22976

[15] Xie X, Zhong Z, Zhao W, Zheng C, Wang F, Liu J. Chest CT for Typical 2019-nCoV Pneumonia: Relationship to Negative RT-PCR Testing [published online ahead of print, 2020 Feb 12]. Radiology. 2020;200343. doi:10. 1148/radiol. 2020200343

[16] Corman VM, Landt 0, Kaiser M, et al. Detection of 2019 novel coronavirus (2019-nCoV) by real-time RT-PCR. Euro Surveil1. $2020 ; 25$ (3) :2000045. doi :10. 2807/1560-7917. ES. 2020. 25. 3. 2000045

[17] Lippi G, Simundic AM, Plebani M. Potential preanalytical and analytical vulnerabilities in the laboratory diagnosis of coronavirus disease 2019 (COVID-19) [published online ahead of 
medRxiv preprint doi: https://doi.org/10.1101/2020.04.02.20050914; this version posted April 28, 2020. The copyright holder for this preprint (which was not certified by peer review) is the author/funder, who has granted medRxiv a license to display the preprint in perpetuity.

It is made available under a CC-BY-NC-ND 4.0 International license.

print, 2020 Mar 16]. Clin Chem Lab Med. 2020;/j/cclm. ahead-ofprint/cclm-2020-0285/cclm-2020-0285. xm1. doi:10. 1515/cc1m-2020-0285

[18] Udugama B, Kadhiresan P, Kozlowski HN, et al. Diagnosing COVID-19: The Disease and Tools for Detection [published online ahead of print, 2020 Mar 30]. ACS Nano. 2020;10. 1021/acsnano. 0c02624. doi:10. 1021/acsnano. 0c02624

[19] Peto Julian. Covid-19 mass testing facilities could end the epidemic rapidly BMJ 2020; $368: m 1163$

[20] Hellewell J, Abbott S, Gimma A, et al. Feasibility of controlling COVID-19 outbreaks by isolation of cases and contacts [published correction appears in Lancet Glob Health. 2020 Mar 5;:]. Lancet Glob Health. 2020;8(4) : e488 - e496. doi:10. 1016/S2214-109X (20) 30074-7

[21] Burke RM, Midgley CM, Dratch A, et al. Active Monitoring of Persons Exposed to Patients with Confirmed COVID-19 - United States, January-February 2020. MMWR Morb Mortal Wkly Rep. 2020;69(9) :245 246. Published 2020 Mar 6. doi:10. 15585/mmwr.mm6909e1

[22] Jin YH, Cai L, Cheng ZS, et al. A rapid advice guideline for the diagnosis and treatment of 2019 novel coronavirus (2019-nCoV) infected pneumonia (standard version). Mil Med Res. 2020;7(1):4. Published 2020 Feb 6. doi:10. 1186/s40779-020-0233-6

[23] http://www. nhc. gov. cn/yzygj/s7653p/202001/f492c9153ea9437bb587ce2ffc bee1fa. shtm1. [2020-01-23]

[24] http://www. nhc. gov.cn/yzygj/s7652m/202001/7450028ab6084101ae8110f0aa f81271. shtm1. [2020-01-28 ]

[25] http://www. nhc. gov. cn/yzygj/s7653p/202002/d4b895337e19445f8d728fcaf1 e3e13a. shtm1. [2020-02-08]

[26] Diagnosis and Treatment Plan for COVID-19 (Trial Version 6) [published online ahead of print, 2020 Mar 17]. Chin Med J (Eng1). 2020;10. 1097/CM9. 0000000000000819. doi:10. 1097/CM9. 0000000000000819

[27] http://www. nhc. gov. cn/yzygj/s7653p/202003/46c9294a7dfe4cef80dc7f5912 eb1989. shtm1. [2020-03-04] 
medRxiv preprint doi: https://doi.org/10.1101/2020.04.02.20050914; this version posted April 28, 2020. The copyright holder for this preprint (which was not certified by peer review) is the author/funder, who has granted medRxiv a license to display the preprint in perpetuity. It is made available under a CC-BY-NC-ND 4.0 International license .

\section{Competing Interest Statement}

The authors declare no competing interests.

\section{Funding Statement}

There is no external funding, and there is no conflict of interest.

\section{Author Declaration}

All relevant ethical guidelines have been followed; any necessary IRB and/or ethics committee approvals have been obtained, and details of the IRB/oversight body are included in the manuscript.

Yes

All necessary patient/participant consent was obtained, and the appropriate institutional forms were archived.

Yes

I understand that all clinical trials and any other prospective interventional studies must be registered with an ICMJE-approved registry, such as ClinicalTrials.gov. I confirm that any such study reported in the manuscript has been registered and the trial registration ID is provided (note: if posting a prospective study registered retrospectively. Please provide a statement in the trial ID field explaining why the study was not registered in advance).

Yes

I have followed all appropriate research reporting guidelines and uploaded the relevant EQUATOR Network research reporting checklist(s) and other pertinent materials as supplementary files, if applicable.

Yes 